\title{
Pelleted Beet Pulp Substituted for High-Moisture Corn: 3. Effects on Ruminal Fermentation, pH, and Microbial Protein Efficiency in Lactating Dairy Cows
}

\author{
J. A. Voelker and M. S. Allen \\ Department of Animal Science \\ Michigan State University, \\ East Lansing 48824-1225
}

\begin{abstract}
The effects of increasing concentrations of dried, pelleted beet pulp substituted for high-moisture corn on ruminal fermentation, $\mathrm{pH}$, and microbial efficiency were evaluated using eight ruminally and duodenally cannulated multiparous Holstein cows in a duplicated $4 \times 4$ Latin square design with 21 -d periods. Cows were $79 \pm 17$ (mean \pm SD) DIM at the beginning of the experiment. Experimental diets with $40 \%$ forage (corn silage and alfalfa silage) and $60 \%$ concentrate contained 0 , $6.1,12.1$, or $24.3 \%$ beet pulp substituted for high-moisture corn on a DM basis. Diet concentrations of NDF and starch were 24.3 and $34.6 \%$ (0\% beet pulp), 26.2 and $30.5 \%$ (6\% beet pulp), 28.0, and $26.5 \%$ (12\% beet pulp), and 31.6 and $18.4 \%$ (24\% beet pulp), respectively. Substituting beet pulp for corn did not affect daily mean or minimum ruminal $\mathrm{pH}$ but tended to reduce $\mathrm{pH}$ range. Ruminal acetate:propionate responded in a positive exponential relationship to added beet pulp. Rate of valerate absorption from the rumen was not affected by treatment. Substituting beet pulp for corn up to $24 \%$ of diet DM did not affect efficiency of ruminal microbial protein production, expressed as microbial $\mathrm{N}$ flow to the duodenum as a percentage of OM truly digested in the rumen. Microbial efficiency was not correlated to mean $\mathrm{pH}$ or daily minimum $\mathrm{pH}$. While microbial efficiency was not directly related to concentration of beet pulp fed, it was positively correlated with passage rate of particulate matter, as represented by starch and indigestible NDF, probably due to reduced turnover of microbial protein in the rumen.
\end{abstract}

(Key words: beet pulp, high-moisture corn, fermentation, microbial efficiency)

Abbreviation key: $\mathbf{B P}=$ beet pulp, $\mathbf{0 B P}=0 \%$ beet pulp treatment, $\mathbf{6 B P}=6 \%$ beet pulp treatment, 12BP $=12 \%$ beet pulp treatment, $\mathbf{2 4 B P}=24 \%$ beet pulp treat-

Received November 12, 2002.

Accepted March 3, 2003.

Corresponding author: M. S. Allen; e-mail: allenm@pilot.msu.edu. ment, $\mathbf{H M C}$ = high-moisture corn, INDF = indigestible NDF, $\mathbf{p d N D F}=$ potentially digestible NDF, $\mathbf{M N E}=$ microbial $\mathrm{N}$ efficiency.

\section{INTRODUCTION}

Achieving optimal temporal patterns of ruminal carbohydrate fermentation is necessary to maximize milk yield and efficiency in dairy cattle, because their primary sources of energy and protein are fermentation products, especially VFA and microbial protein. Dietary starch concentration is often increased in order to increase diet fermentability, but increasing rate, or even extent, of ruminal fermentation does not necessarily result in optimal fermentation. Replacing feed ingredients high in cellulose and hemicellulose with ingredients high in starch usually increases ruminal production of VFA and alters the proportions of individual VFA produced. Absorbed propionate can reduce feed intake (Anil and Forbes, 1980) and may alter nutrient partitioning and milk production. Greater VFA production can lead to reduced ruminal $\mathrm{pH}$, which might increase the rate of VFA absorption from the rumen (Dijkstra et al., 1993). Low ruminal $\mathrm{pH}$ inhibits fiber digestion (Ørskov and Fraser, 1975) and decreases microbial efficiency because of increased lysis (Russell and Wilson, 1996). Therefore, optimal ruminal fermentation for high-concentrate diets probably can be achieved by diluting starch with a nonforage carbohydrate source that is less rapidly fermented, produces less propionate, and does not reduce ruminal $\mathrm{pH}$. The NDF in beet pulp can be digested more quickly than forage NDF (Bhatti and Firkins, 1995), and pectin, which is not recovered in NDF, is degraded more rapidly than cellulose and hemicellulose, but pectinolytic bacteria are also inhibited at low pH (Marounek et al., 1985). Substituting beet pulp for high-moisture corn in a diet with moderately low forage content should alter ruminal fermentation and might increase mean or minimum ruminal $\mathrm{pH}$. If beet pulp improves microbial utilization of energy or reduces microbial protein turnover in the rumen, microbial protein efficiency may be improved. The ob- 
Table 1. Nutrient composition of high-moisture corn and dried, pelleted beet pulp.

\begin{tabular}{llr}
\hline Nutrient & $\begin{array}{l}\text { High-moisture } \\
\text { corn }\end{array}$ & $\begin{array}{r}\text { Beet } \\
\text { pulp }\end{array}$ \\
\hline DM, \% as fed & 71.5 & 84.9 \\
\cline { 2 - 3 } & 10.0 & \% of DM \\
NDF & 8.3 & 39.9 \\
CP & 3.8 & 8.9 \\
Indigestible NDF & 70.5 & 8.0 \\
Starch & 4.7 & 3.9 \\
Ether extract & 1.0 & 0.7 \\
Ash & & 7.8 \\
\hline
\end{tabular}

jective of this experiment was to characterize the responses of ruminal fermentation, $\mathrm{pH}$, and microbial protein efficiency to beet pulp substituted for high-moisture corn at $0,6,12$, and $24 \%$ of diet DM.

\section{MATERIALS AND METHODS}

This paper is one of three papers in a series from one experiment that evaluated effects of the substitution of dried, pelleted beet pulp for high-moisture corn. This paper discusses treatment effects on ruminal fermentation, including efficiency of microbial nitrogen production, and the companion papers focus on feed intake and milk production (Voelker and Allen, 2003a) and on digestion (Voelker and Allen, 2003b).

\section{Treatments and Cows}

Experimental procedures were approved by the All University Committee on Animal Use and Care at Michigan State University. Eight multiparous Holstein cows (79 \pm 17 DIM; mean \pm SD) from the Michigan State University Dairy Cattle Teaching and Research Center were assigned randomly to a duplicated $4 \times 4$ Latin square balanced for carryover effects in a doseresponse arrangement of treatments. Treatments were diets containing dried, pelleted beet pulp (BP) substituted for high-moisture corn (HMC) at 0 (0BP), 6 (6BP), $12(\mathbf{1 2 B P})$, and 24\% (24BP) of diet DM. Treatment periods were $21 \mathrm{~d}$, with the final $10 \mathrm{~d}$ used to collect samples and data. Cows were cannulated ruminally and duodenally before calving as previously described (Voelker and Allen, 2003b). Nutrient composition for HMC and BP are shown in Table 1. Experimental diets contained 40\% forage (50:50 corn silage: alfalfa silage), HMC, BP at 0 to $24 \%$ of diet DM, a premixed protein supplement (soybean meal, corn distiller's grains, and bloodmeal), and a mineral and vitamin mix (Table 2). All diets were formulated for $18 \%$ dietary CP concentration and fed as TMR.

\section{Data and Sample Collection}

Throughout the experiment, cows were housed and fed as previously described (Voelker and Allen, 2003a).

Table 2. Ingredient and nutrient composition of experimental diets.

\begin{tabular}{|c|c|c|c|c|}
\hline & $0 \% \mathrm{BP}$ & $6 \% \mathrm{BP}$ & $12 \% \mathrm{BP}$ & $24 \% \mathrm{BP}$ \\
\hline \multicolumn{5}{|l|}{ Ingredients } \\
\hline Corn silage $^{1}$ & 20.1 & 20.1 & 20.1 & 20.1 \\
\hline Alfalfa silage $^{2}$ & 19.9 & 19.9 & 19.9 & 19.9 \\
\hline Protein mix $^{3}$ & 19.5 & 19.5 & 19.5 & 19.5 \\
\hline Mineral vitamin $\operatorname{mix}^{4}$ & 4.8 & 4.8 & 4.8 & 4.8 \\
\hline Dried, pelleted beet pulp & 0 & 6.1 & 12.1 & 24.3 \\
\hline High-moisture corn & 35.6 & 29.5 & 23.5 & 11.4 \\
\hline \multicolumn{5}{|l|}{ Nutrient } \\
\hline $\mathrm{DM}$ & 50.2 & 50.5 & 50.8 & 51.6 \\
\hline Starch & 34.6 & 30.5 & 26.5 & 18.4 \\
\hline NDF & 24.3 & 26.2 & 28.0 & 31.6 \\
\hline Indigestible NDF & 9.4 & 9.6 & 9.8 & 10.2 \\
\hline Forage NDF & 17.1 & 17.1 & 17.1 & 17.1 \\
\hline $\mathrm{CP}$ & 18.0 & 18.0 & 18.0 & 18.1 \\
\hline Rumen-undegraded $\mathrm{CP}^{5}$ & 11.6 & 11.4 & 11.3 & 10.9 \\
\hline \multicolumn{5}{|l|}{$\%$ Starch from } \\
\hline high-moisture corn & 72.7 & 68.3 & 62.6 & 43.7 \\
\hline$\%$ NDF from forage & 70.2 & 65.3 & 61.1 & 54.1 \\
\hline$\%$ NDF from beet pulp & 0.0 & 9.3 & 17.3 & 30.7 \\
\hline
\end{tabular}

${ }^{1}$ Corn silage contained $36.2 \% \mathrm{DM}$ (as fed) and (DM basis) $43.5 \% \mathrm{NDF}, 7.6 \% \mathrm{CP}, 13.4 \%$ indigestible NDF, $28.5 \%$ starch, and $3.8 \%$ ash. $\mathrm{BP}=$ beat pulp.

${ }^{2}$ Alfalfa silage contained $34.6 \% \mathrm{DM}$ (as fed) and (DM basis) $41.8 \% \mathrm{NDF}, 19.5 \% \mathrm{CP}, 26.1 \%$ indigestible NDF, $3.0 \%$ starch, and $8.1 \%$ ash.

${ }^{3}$ Protein mix contained 75\% soybean meal, 20\% corn distillers' grains (with solubles), and 5\% blood meal.

${ }^{4}$ Mineral vitamin mix contained $10.4 \%$ trace mineral premix, $0.4 \%$ vitamin $\mathrm{D}, 0.4 \%$ vitamin $\mathrm{A}, 2.7 \%$ magnesium oxide, $22.3 \%$ dicalcium phosphate, and $63.8 \%$ dry ground corn as a carrier.

${ }^{5}$ Rumen-degraded protein estimated using values from NRC (2001). 
Duodenal digesta, fecal, rumen fluid for VFA (100 ml), and rumen fluid for microbial pellet $(350 \mathrm{ml})$ were sampled every $9 \mathrm{~h}$ as previously described (Voelker and Allen, 2003b). Rumen fluid for the microbial pellet was collected from the reticulum, near the reticular-omasal orifice, and strained through a layer of nylon mesh $(\sim 1$ $\mathrm{mm}$ pore size). For rumen fluid VFA analysis, digesta obtained from five sites in the rumen was combined and strained, and fluid $\mathrm{pH}$ was immediately recorded. Duodenal, fecal, and rumen fluid VFA and microbial pellet samples were immediately frozen at $-20^{\circ} \mathrm{C}$. Effect of treatment on rate of liquid passage and relative rate of valerate absorption was measured on d 15 using a pulse dose of valeric acid and Co-EDTA (Allen et al., 2000). Valeric acid and Co-EDTA were dosed $2 \mathrm{~h}$ after feeding. Rumen fluid was sampled before dosing and at $0.5,1,1.5,2,2.5,3,3.5,4,4.5,5,5.5,6,6.5,7,7.5$, and $8 \mathrm{~h}$ after dosing. Samples were immediately frozen. Ruminal $\mathrm{pH}$ was monitored from d 16 through d 19 (96 h) of each period by a computerized data acquisition system (Dado and Allen, 1993). Ruminal pH data were recorded for each cow every $5 \mathrm{~s}$. Electrodes for ruminal $\mathrm{pH}$ determination were checked daily and calibrated as needed, and ruminal $\mathrm{pH}$ data were deleted for the previous $24 \mathrm{~h}$ if readings had changed more than 0.05 $\mathrm{U}$ at $\mathrm{pH} 7$ or 4 . The system successfully collected $66.1 \%$ of the total ruminal $\mathrm{pH}$ data (average $2.7 \mathrm{~d}$ per cow per period). Daily mean, minimum, maximum, variation range, time below $\mathrm{pH} 6.0,5.8$, and 5.5, and area below $\mathrm{pH} 6.0,5.8$, and $5.5($ time $\times \mathrm{pH})$ were calculated. Response variables were averaged over $4 \mathrm{~d}$ for each period. Ruminal contents were evacuated and sampled as previously described (Voelker and Allen, 2003b). At rumen emptying, two additional liquid samples were obtained to measure VFA content and rumen fluid consistency. All samples, except the consistency sample, were frozen immediately at $-20^{\circ} \mathrm{C}$. After each rumen evacuation, $20 \mathrm{ml}$ of rumen fluid (maintained at $37^{\circ} \mathrm{C}$ in a waterbath) were used to measure consistency in a clean, dry Bostwick consistometer (CSC Scientific Co., Fairfax, VA). Distance traveled by the liquid front $(\mathrm{cm})$ was recorded every $30 \mathrm{~s}$ for $300 \mathrm{~s}$, and samples were run in duplicate. Data reported are the distance traveled after $300 \mathrm{~s}$.

\section{Sample and Statistical Analysis}

Samples of diet ingredients, orts, ruminal contents, duodenal digesta, and feces were processed and analyzed as previously described (Voelker and Allen, 2003a, 2003b). Ruminal fluid was analyzed for concentration of major VFA and lactate by HPLC (Waters Corp., Milford, MA). Duodenal digesta was analyzed for purines and ammonia to estimate microbial $\mathrm{N}$ flow and nonammonia nonmicrobial $\mathrm{N}$ flow to the duodenum. Purine concentration was used as a microbial marker, and purine to microbial $\mathrm{N}$ ratio was estimated by analysis of microbial pellets. Total purines were measured by spectrophotometer (Beckman Instruments, Inc., Fullerton, CA) at $260 \mathrm{~nm}$ (Zinn and Owens, 1986). Ammonia concentration was determined for centrifuged duodenal and rumen fluid samples according to Broderick and Kang (1980). Rumen fluid samples collected to measure rate of valerate absorption were analyzed for valerate concentration by HPLC (Waters Corp.) and for Coconcentration by atomic absorption spectrophotometry (SpectrAA 220/FS, Varian Australia Pty. Ltd., Mulgrave, Victoria, Australia). Rates of valerate and cobalt disappearance were determined by nonlinear regression of the decline in their respective concentrations in rumen fluid over time after dosing, accounting for background (JMP Version 4, SAS Institute, Cary, NC). All data were analyzed using the fit model procedure of JMP according to the following model:

$$
\mathrm{Y}_{\mathrm{ijkl}}=\mu+\mathrm{C}_{\mathrm{i}}+\mathrm{P}_{\mathrm{j}}+\mathrm{T}_{\mathrm{k}}+\mathrm{e}_{\mathrm{ijk}} \text {, }
$$

where $\mu$ = overall mean, $\mathrm{C}_{\mathrm{i}}=$ random effect of cow $(\mathrm{i}=$ 1 to 8), $P_{j}=$ fixed effect of period ( $\mathrm{j}=1$ to 4$), \mathrm{T}_{\mathrm{k}}=$ fixed effect of treatment ( $\mathrm{k}=1$ to 4$)$, and $\mathrm{e}_{\mathrm{ijk}}=$ residual, assumed to be normally distributed. Period $\times$ treatment interaction was originally evaluated, but it was removed from the statistical model because it was not significant for response variables of primary interest. Linear and quadratic dose-response effects were evaluated using the same model with diet percent BP in place of the fixed effect of treatment. Pearson's correlation coefficients were determined between cow-period observations for some parameters. Treatment effects, linear and quadratic responses, and correlations were declared significant at $P<0.05$, and tendencies were declared at $P<0.10$. Data from two cow-periods were excluded from statistical analysis for reasons previously described (Voelker and Allen, 2003a).

\section{RESULTS AND DISCUSSION}

\section{Ruminal pH}

A primary hypothesis regarding the substitution of fibrous BP for HMC was that feeding diets containing high concentrations of rapidly fermentable grain would result in lower average and nadir ruminal $\mathrm{pH}$ values, and that the pectin and insoluble fiber in BP would attenuate this decrease. Diets ranged from 35\% starch and $24 \% \mathrm{NDF}$ in $0 \mathrm{BP}$ to $18 \%$ starch and $32 \% \mathrm{NDF}$ in $24 \mathrm{BP}$, but when $\mathrm{pH}$ was averaged from continuous collection over $4 \mathrm{~d}$, no difference existed between treat- 
Table 3. Effects of substitution of pelleted beet pulp for high-moisture corn on ruminal $\mathrm{pH}$.

\begin{tabular}{|c|c|c|c|c|c|c|c|c|}
\hline \multirow[b]{2}{*}{ Daily ruminal $\mathrm{pH}$} & \multicolumn{5}{|c|}{ Treatment LS Means $^{1}$} & \multicolumn{3}{|c|}{$P^{2}$} \\
\hline & $0 \% \mathrm{BP}$ & $6 \% \mathrm{BP}$ & $12 \% \mathrm{BP}$ & $24 \% \mathrm{BP}$ & $\mathrm{SE}$ & Trt & $\mathrm{L}$ & Q \\
\hline Mean & 5.93 & 5.97 & 6.02 & 5.94 & 0.10 & 0.53 & 0.16 & 0.17 \\
\hline Minimum & 5.36 & 5.39 & 5.40 & 5.47 & 0.12 & 0.59 & 0.16 & 0.95 \\
\hline Maximum & 6.56 & 6.55 & 6.55 & 6.43 & 0.08 & 0.17 & 0.05 & 0.28 \\
\hline Range & 1.23 & 1.19 & 1.06 & 1.07 & 0.09 & 0.24 & 0.07 & 0.50 \\
\hline Variance & 0.14 & 0.12 & 0.11 & 0.11 & 0.02 & 0.42 & 0.17 & 0.34 \\
\hline Standard deviation & 0.36 & 0.34 & 0.32 & 0.33 & 0.03 & 0.40 & 0.14 & 0.26 \\
\hline Time $<6.0 \mathrm{~h}$ & 12.9 & 12.0 & 12.1 & 13.8 & 2.2 & 0.43 & 0.26 & 0.15 \\
\hline Area below $6.0, \mathrm{~h}$ & 634 & 565 & 481 & 591 & 149 & 0.65 & 0.22 & 0.24 \\
\hline
\end{tabular}

${ }^{1}$ Treatments were beet pulp (BP) substituted for high-moisture corn as $0,6,12$, and $24 \%$ of diet DM.

${ }^{2}$ Trt: treatment effect, L: linear effect, Q: quadratic effect.

ments (Table 3 ). Daily minimum $\mathrm{pH}$ was not affected by treatment, but daily maximum $\mathrm{pH}$ decreased linearly as BP increased $(P=0.05)$, reducing the range of $\mathrm{pH}(P=0.07)$. Decreasing range and maximum $\mathrm{pH}$ suggest that substituting BP for HMC might have reduced diurnal variation in ruminal $\mathrm{pH}$, but variance and standard deviation did not decrease. Measures of time and area (time $\times \mathrm{pH}$ ) below $\mathrm{pH} 6.0,5.8$, and 5.5 were not affected by treatment. Mean $\mathrm{pH}$ was near the $\mathrm{pK}_{\mathrm{a}}$ of bicarbonate for all treatments. It is possible that the remaining buffering capacity of the rumen fluid, especially the bicarbonate system, was different between treatments while ruminal $\mathrm{pH}$ was similar across treatments (Allen, 1997). Therefore, measurement of rumen fluid buffering capacity would be useful in future studies of effects of carbohydrate source on the rumen environment.

\section{Ruminal Volatile Fatty Acid Concentration and Removal}

Total VFA concentration in rumen fluid was similar across treatments (Table 4 ), but the response of ruminal VFA pool (mol) to increasing BP was quadratic $(P<$ 0.05 ) with the largest VFA pool for cows fed 12BP. Rate of valerate absorption from the rumen, an estimate of VFA absorption, was similar (approximately $40 \% / \mathrm{h}$ ) for all treatments. Ruminal liquid dilution rate was reduced by the substitution of BP for HMC ( $P=0.03)$, so VFA probably escaped more slowly in liquid for diets containing more BP, and a larger proportion of VFA produced may have been absorbed across the rumen wall. Because BP contains high concentrations of pectin, which gelatinizes under the appropriate conditions, rumen fluid consistency was also measured. Rumen fluid consistency was not different among treatments $(P>0.40)$. However, across cow-period observations, there was a quadratic relationship between liquid passage rate and consistency [passage rate $=0.163+$ $0.00128 \times$ consistency $-0.000946 \times(\text { consistency }-14.4)^{2}$;
$\mathrm{R}=0.52, P=0.02]$. This suggests that consistency and at least one other factor affected liquid passage rate. Despite large differences in starch content among diets, lactate concentration was similar for $0 \mathrm{BP}, 6 \mathrm{BP}$, and 12BP $(P>0.25)$. Another experiment comparing beet pulp and corn grain also reported no difference in lactate concentration (O'Mara et al., 1997). As expected, substituting BP for HMC increased the molar proportion of acetate $(P<0.0001)$ and butyrate $(P<0.05)$ in total VFA, and decreased the molar proportion of propionate $(P<0.001)$. Branched-chain VFA were lower for 24BP than for the other diets (quadratic $P=0.04$ ), suggesting that proteolysis was reduced and (or) that incorporation of branched-chain amino acids into microbial protein was increased. Fermentation results of other in vivo experiments comparing beet pulp and corn grain in TMR have varied; the only experiment detecting fermentation acid effects (Clark and Armentano, 1997) reported results similar to those in this experiment for acetate, propionate, and butyrate. Volatile fatty acid concentrations resulting from comparisons of beet pulp and grain in continuous culture differ from in vivo results. Two studies (Chester-Jones et al., 1991; Mansfield et al., 1994) reported greater acetate and lower butyrate concentrations with beet pulp replacing corn grain, and these two and another (Bach et al., 1999) reported no effect on propionate concentration. Differences between in vitro and in vivo responses may be because of differential rates of VFA absorption from the rumen (Dijkstra et al., 1993).

\section{Ruminal pH and VFA}

Among cow-period observations, both slower absorption of VFA and slower liquid passage from the rumen led to higher VFA concentrations in the rumen (Figure $1 \mathrm{a}$ and $\mathrm{b}$ ); VFA concentration was negatively correlated with rate of valerate absorption $(\mathrm{R}=-0.70, P<0.0001)$ and with liquid passage rate $(\mathrm{R}=-0.54, P<0.01)$. As VFA concentration increased, ruminal $\mathrm{pH}$ decreased $(\mathrm{R}$ 
Table 4. Effects of substitution of pelleted beet pulp for high-moisture corn on ruminal fermentation, and VFA removal.

\begin{tabular}{|c|c|c|c|c|c|c|c|c|}
\hline & \multicolumn{5}{|c|}{ Treatment LS Means $^{1}$} & \multicolumn{3}{|c|}{$P^{2}$} \\
\hline & $0 \% \mathrm{BP}$ & $6 \% \mathrm{BP}$ & $12 \% \mathrm{BP}$ & $24 \% \mathrm{BP}$ & $\mathrm{SE}$ & Trt & $\mathrm{L}$ & Q \\
\hline Total VFA, mM & 138 & 141 & 142 & 142 & 3 & 0.35 & 0.14 & 0.26 \\
\hline Total ruminal VFA pool, mol & 3.99 & 4.10 & 4.63 & 3.83 & 0.32 & 0.12 & 0.07 & $<0.05$ \\
\hline Rate of valerate absorption, $\%$; h & 41.3 & 43.2 & 37.3 & 40.0 & 4.0 & 0.51 & 0.57 & 0.69 \\
\hline Liquid passage rate, $\% / \mathrm{h}^{3}$ & 18.6 & 17.5 & 16.7 & 16.6 & 1.0 & 0.13 & 0.03 & 0.21 \\
\hline Rumen fluid consistency ${ }^{4}$ & 14.6 & 14.2 & 14.0 & 15.1 & 1.3 & 0.84 & 0.51 & 0.42 \\
\hline Lactate, $\mathrm{m} M$ & 0.30 & 0.31 & 0.26 & 0.08 & 0.16 & 0.72 & 0.27 & 0.64 \\
\hline \multicolumn{9}{|l|}{ VFA, mol/100 mol } \\
\hline Acetate & 56.9 & 59.1 & 60.2 & 61.6 & 1.1 & $<0.01$ & $<0.01$ & 0.04 \\
\hline Propionate & 27.0 & 24.9 & 23.0 & 22.4 & 1.1 & $<0.01$ & $<0.01$ & 0.04 \\
\hline Butyrate & 11.3 & 11.5 & 12.2 & 12.3 & 0.4 & 0.19 & 0.04 & 0.60 \\
\hline Branched-chain VFA & 2.33 & 2.34 & 2.31 & 1.85 & 0.09 & $<0.01$ & 0.28 & 0.01 \\
\hline Acetate:Propionate & 2.19 & 2.45 & 2.69 & 2.80 & 0.16 & $<0.01$ & $<0.01$ & 0.04 \\
\hline
\end{tabular}

${ }^{1}$ Treatments were beet pulp (BP) substituted for high-moisture corn as 0, 6, 12, and $24 \%$ of diet DM.

${ }^{2}$ Trt: treatment effect, L: linear effect, Q: quadratic effect.

${ }^{3}$ Measured using Co-EDTA.

${ }^{4}$ Distance traveled $(\mathrm{cm})$ by front edge of $20 \mathrm{ml}$ rumen liquid in $300 \mathrm{~s}$ in Bostwick's consistometer.

$=-0.47, P=0.03)$ due to greater acid load. Rate of valerate absorption was unexpectedly slower under lower $\mathrm{pH}(\mathrm{R}=0.48, P=0.04)$; because VFA are primarily absorbed in the undissociated state, and because a larger proportion of VFA exist in that form at lower $\mathrm{pH}, \mathrm{VFA}$ absorption usually increases as $\mathrm{pH}$ decreases (Dijkstra et al., 1993). However, in this case, lower ruminal $\mathrm{pH}$ might have decreased rumen motility, resulting in less thorough mixing of ruminal contents and thus a slower rate of VFA absorption. Although rumen motility was not measured, valerate absorption rate increased with greater passage rate of indigestible NDF (Table 5; $\mathrm{R}=0.43, P=0.02$ ) and tended to increase with greater liquid passage rate (Table $6 ; \mathrm{R}=0.33, P=0.08$ ), which might be indicators of rumen motility. However, passage rate and thus VFA absorption might have been affected by DMI along with or instead of $\mathrm{pH}$, as rate of valerate absorption also tended to increase with increasing DMI $(\mathrm{R}=0.31, P<0.10)$. Finally, greater utilization of metabolic fuels with higher milk yield might have created a greater gradient of VFA concentrations across the rumen wall, demonstrated by an increase in valerate absorption rate with greater FCM yield $(\mathrm{R}=$ $0.49, P<0.01)$.

\section{Ruminal Nitrogen Digestion}

Ruminal ammonia concentration responded in a quadratic relationship to dietary $\mathrm{BP}$ concentration $(P=$ 0.04 ), with the maximum concentration for $12 \mathrm{BP}$ and the lowest concentration for 24BP. Across treatments, ruminal ammonia concentration was not correlated with ruminal $\mathrm{pH}$ (Table 7). Ammonia availability probably did not limit microbial protein synthesis for any of the diets, because maximum microbial $\mathrm{N}$ production occurs at $5 \mathrm{mg} / \mathrm{dl}$, far below the values in this experiment, and does not increase at higher ammonia concentrations (Satter and Slyter, 1974). Some amylolyticmicrobes exhibit extensive proteolysis (Russell et al., 1981), and the additional ammonia $\mathrm{N}$ can be used for protein synthesis, absorbed across the rumen wall, or may flow to the duodenum. Microbes which primarily degrade nonstructural carbohydrates obtain approximately two-thirds of their $\mathrm{N}$ from amino acids and peptides, not ammonia (Russell et al., 1983), while fibrolytic microbes obtain all $\mathrm{N}$ for protein synthesis from ammonia (Bryant, 1973). The rate of incorporation of ammonia into protein for 12BP may not have been sufficient to utilize the ammonia made available by deamination, resulting in a higher ammonia concentration.

\section{Microbial Nitrogen Efficiency}

Flow of microbial $\mathrm{N}$ in the duodenum decreased linearly $(P=0.04)$ as BP was substituted for HMC (Table 6). Mean efficiency of conversion of truly ruminally degraded OM (TRDOM) to microbial N (MNE) ranged from 36.4 to $41.4 \mathrm{~g} / \mathrm{kg}$ TRDOM, and these values are within the range of previously published values of ap-

Table 5. Pearson correlation coefficients for ruminal VFA concentration and related variables.

\begin{tabular}{llll}
\hline & $(1)$ & $(2)$ & $(3)$ \\
\hline (1) Ruminal [VFA], $\mathrm{m} M$ & $\ldots$ & $\ldots$ & $\ldots$ \\
(2) $\mathrm{pH}$, daily mean & $-0.43^{1}$ & $\ldots$ & $\ldots$ \\
(3) Valerate absorption rate, \%/h & $-0.69^{1}$ & $0.40^{1}$ & $\ldots$ \\
(4) Liquid passage rate, \%/h & $-0.49^{1}$ & 0.15 & 0.28 \\
\hline
\end{tabular}

${ }^{1}$ Correlation is significant $(P<0.05)$. 
(a)

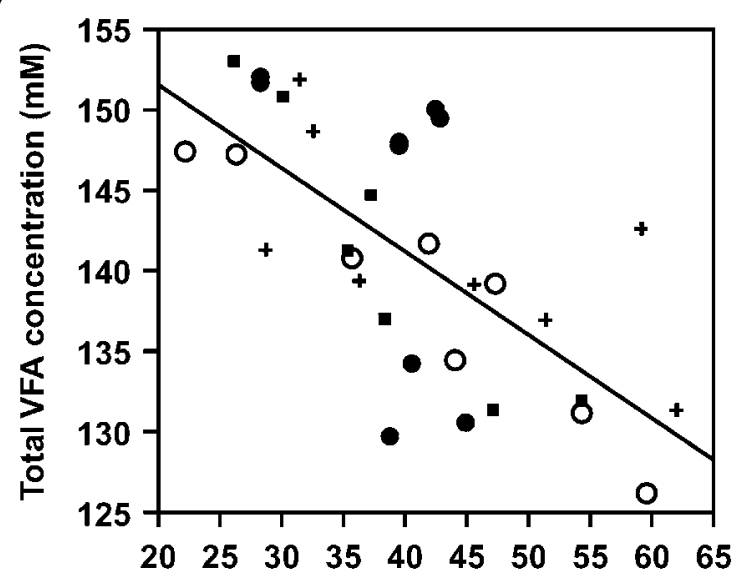

Rate of valerate absorption $(\% / h)$

(b)

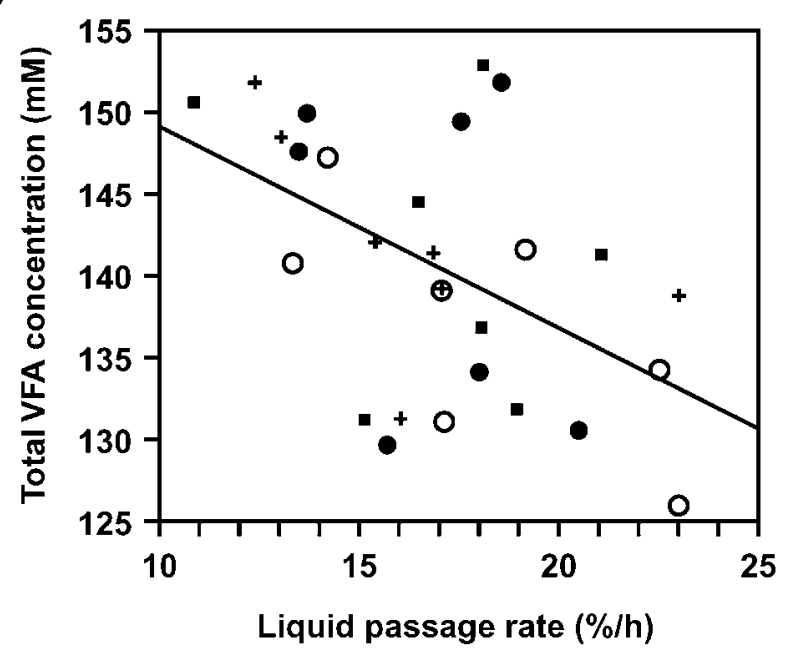

Figure 1. Relationship between VFA concentration in rumen fluid and (a) rate of valerate absorption ([VFA] $=162-52 \times$ rate of valerate absorption ; $\mathrm{R}=-0.69 ; P<0.01$ ); and (b) liquid passage rate ([VFA] $=162-1233 \times$ liquid passage rate; $\mathrm{R}=-0.49 ; P<0.01) . \bigcirc$ denotes $0 \%$ beet pulp, + denotes $6 \%$ beet pulp, denotes $12 \%$ beet pulp, and denotes $24 \%$ beet pulp (\% diet DM) substituted for highmoisture corn.

proximately 10 to $50 \mathrm{~g} / \mathrm{kg}$ TRDOM (Clark et al., 1992). However, MNE was not different among treatments $(P$ $>0.25$ ), even though diets varied widely in starch and $\mathrm{NDF}$ content. Whereas microbial $\mathrm{N}$ flow decreased with added BP, kilograms of TRDOM decreased numerically (not statistically; Voelker and Allen, 2003b), so the absence of a MNE treatment effect might have been caused by concurrent decreases in both microbial $\mathrm{N}$ flow and $\mathrm{kg}$ of $\mathrm{OM}$ ruminally digested. Ruminal concentrations of amino acids and peptides were not measured in the present experiment, but their availability can limit the rate of growth for amylolytic bacteria (Van
Kessel and Russell, 1996). However, diets in this experiment were formulated for sufficient RDP; animals were fed $18 \%$ dietary $\mathrm{CP}(\%$ of $\mathrm{DM})$ with observed RDP ranging from 55 to $60 \%$ (duodenal NANMN flow ranged from 44.6 to $40.2 \%$ of $\mathrm{N}$ intake). Soybean meal was the primary protein supplement (32 to $36 \%$ of total dietary $\mathrm{CP}$ ), and soybean meal increases microbial $\mathrm{N}$ flow compared with other protein supplements (Clark et al., 1992). Therefore, it is unlikely that amino acid or peptide availability limited microbial growth for the highstarch diets. Cows absorbed less NAN in the intestines $(P=0.03)$ because NAN flow to the duodenum decreased with increasing BP $(P=0.02)$, but total $\mathrm{N}$ absorbed $(\mathrm{kg} /$ d) and total tract digestibility of $\mathrm{N}$ were not affected by treatment.

\section{Microbial Nitrogen Efficiency and Fermentation}

As described above, efficiency of microbial protein production was not affected by drastically altering the carbohydrate source and thus the pattern of fermentation. Strobel and Russell (1986) suggested that low ruminal $\mathrm{pH}$ causes energy spilling and decreases the efficiency with which microbes convert feed energy and $\mathrm{N}$ into protein. However, when data from all cow-periods in this experiment were pooled, MNE was not associated with mean ruminal $\mathrm{pH}$ (Table 7) or with any other measure of ruminal $\mathrm{pH}$ (data not shown). The range of cow-period mean $\mathrm{pH}$ values was 5.58 to 6.56 , and treatment mean $\mathrm{pH}$ was near 6.0 for all treatments. While MNE was not associated with $\mathrm{pH}$ for this experiment, such a relationship might exist for a range of $\mathrm{pH}$ values below 6.0. Microbial efficiency was not related to ruminal ammonia concentration $(P>0.30)$ or with VFA concentration $(P>0.30)$. Microbial efficiency decreased as ruminal starch digestion rate increased (Figure $2 \mathrm{a} ; \mathrm{R}=-0.52, P<0.01$, and as true ruminal starch digestibility increased (Table $7 ; \mathrm{R}=-0.61, P<0.001$ ). This suggests that bacteria spilled energy instead of using the additional energy for greater protein synthesis. The MNE was not related to the rate or extent of ruminal NDF digestion (data not shown).

\section{Microbial Nitrogen Efficiency and Ruminal Passage Kinetics}

The dominant factor determining efficiency of microbial protein synthesis was the rate at which microbes escaped the rumen, presumably attached to feed particles. The responses most strongly and positively correlated with MNE (Table 7) were the ruminal passage rates of particles of starch (Figure 2b; $\mathrm{R}=0.63, P<$ $0.001)$ and $\operatorname{pdNDF}(\mathrm{R}=0.36, P=0.07)$. Microbes associated with particulate digesta may have escaped the rumen more rapidly, reducing microbial protein turn- 
Table 6. Effects of substitution of pelleted beet pulp for high-moisture corn on $\mathrm{N}$ digestion.

\begin{tabular}{|c|c|c|c|c|c|c|c|c|}
\hline & \multicolumn{5}{|c|}{ Treatment LS Means $^{1}$} & \multicolumn{3}{|c|}{$P^{2}$} \\
\hline & $0 \% \mathrm{BP}$ & $6 \% \mathrm{BP}$ & $12 \% \mathrm{BP}$ & $24 \% \mathrm{BP}$ & $\mathrm{SE}$ & Trt & $\mathrm{L}$ & Q \\
\hline $\mathrm{N}$ intake, g/d & 678 & 692 & 697 & 641 & 21 & 0.18 & 0.23 & 0.09 \\
\hline Ruminal ammonia, mg/dl & 19.6 & 19.3 & 21.4 & 17.8 & 0.9 & 0.02 & 0.09 & 0.04 \\
\hline \multicolumn{9}{|l|}{ Flow to duodenum } \\
\hline Ammonia N, g/d & 19.8 & 20.6 & 21.5 & 19.2 & 1.5 & 0.34 & 0.14 & 0.10 \\
\hline $\mathrm{NAN}^{3} \mathrm{~g} / \mathrm{d}$ & 693 & 707 & 691 & 610 & 32 & 0.09 & 0.02 & 0.19 \\
\hline$\%$ of $\mathrm{N}$ intake & 102.0 & 102.5 & 97.4 & 95.2 & 4.2 & 0.43 & 0.11 & 0.92 \\
\hline \multicolumn{9}{|l|}{ NANMN $^{4}$} \\
\hline $\mathrm{g} / \mathrm{d}$ & 278 & 306 & 287 & 255 & 34 & 0.66 & 0.42 & 0.39 \\
\hline$\%$ of $\mathrm{N}$ intake & 40.8 & 44.6 & 40.5 & 40.2 & 5.1 & 0.85 & 0.74 & 0.69 \\
\hline$\%$ duodenal NAN & 39.7 & 43.0 & 40.9 & 42.1 & 4.4 & 0.90 & 0.74 & 0.74 \\
\hline \multicolumn{9}{|l|}{ Microbial N } \\
\hline $\mathrm{g} / \mathrm{d}$ & 415 & 401 & 404 & 352 & 27 & 0.22 & 0.04 & 0.55 \\
\hline$\%$ duodenal NAN & 60.3 & 57.0 & 59.0 & 57.9 & 4.0 & 0.90 & 0.73 & 0.74 \\
\hline $\mathrm{g} / \mathrm{kg}$ TRDOM $^{5}$ & 36.4 & 41.4 & 40.8 & 39.5 & 3.3 & 0.71 & 0.29 & 0.33 \\
\hline \multicolumn{9}{|l|}{ NAN digested postruminally } \\
\hline $\mathrm{g} / \mathrm{d}$ & 492 & 492 & 485 & 428 & 25 & 0.13 & 0.03 & 0.32 \\
\hline$\%$ of intake & 72.5 & 71.6 & 68.7 & 67.3 & 3.5 & 0.58 & 0.16 & 0.87 \\
\hline$\%$ of duodenal passage & 71.2 & 69.5 & 70.3 & 70.2 & 1.6 & 0.68 & 0.64 & 0.41 \\
\hline \multirow{2}{*}{\multicolumn{9}{|c|}{$\mathrm{N}$ apparently digested in whole tract }} \\
\hline & 476 & 477 & 498 & 458 & 15 & 0.32 & 0.23 & 0.15 \\
\hline$\%$ & 70.5 & 69.1 & 71.7 & 71.5 & 1.6 & 0.40 & 0.31 & 0.84 \\
\hline
\end{tabular}

${ }^{1}$ Treatments were beet pulp (BP) substituted for high-moisture corn as $0,6,12$, and $24 \%$ of diet dry matter.

${ }^{2}$ Trt: treatment effect, L: linear effect, Q: quadratic effect.

${ }^{3}$ Nonammonia N.

${ }^{4}$ Nonammonia non-microbial N.

${ }^{5}$ Truly ruminally digested OM.

over by reducing the effects of autolysis (Wells and Russell, 1996) and protozoal predation (Wallace and McPherson, 1987) on microbial efficiency. Although microbial N flow increased with greater DMI $(\mathrm{R}=0.51, P$ $<0.01)$, microbial efficiency was not related to DMI $(P$ $>0.60$ ), so DMI probably did not cause the increased passage rate and subsequent increased microbial efficiency. Oba and Allen (2002) fed diets containing ground high-moisture corn or ground dry ground corn at two dietary starch concentrations and reported similar responses of MNE, or failures of MNE to respond, to $\mathrm{pH}$, fermentation characteristics, and digestion kinetics in the rumen. They also found no relationship between $\mathrm{MNE}$ and ruminal $\mathrm{pH}$ or ammonia concentration, and they reported that MNE decreased as rate of ruminal starch digestion increased. A positive relationship be-

Table 7. Pearson correlation coefficients for microbial efficiency and related variables.

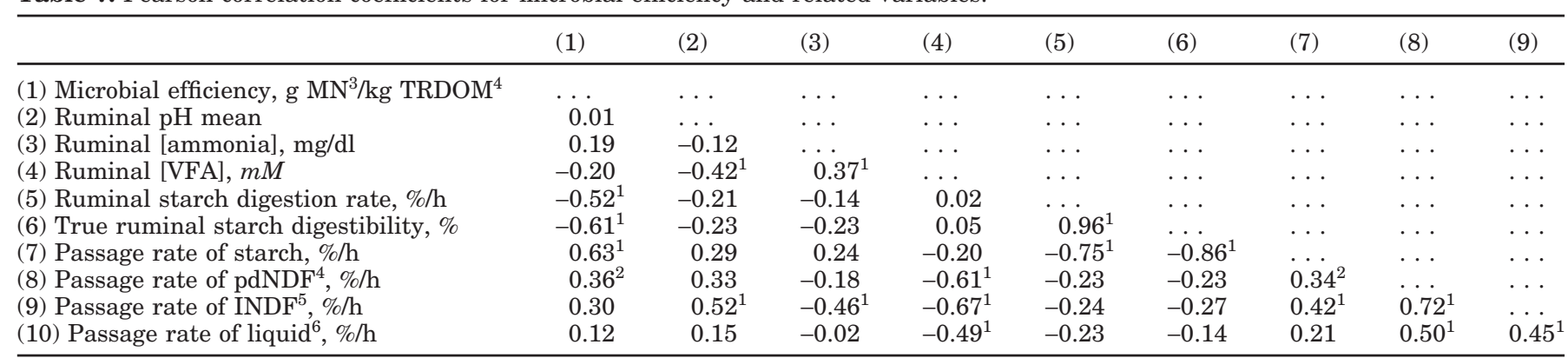

\footnotetext{
${ }^{1}$ Correlation is significant $(P<0.05)$.

${ }^{2}$ Tendency for significant correlation $(P<0.10)$.

${ }^{3}$ Microbial N.

${ }^{4}$ Potentially digestible NDF.

${ }^{5}$ Indigestible NDF.

${ }^{6}$ Measured using Co-EDTA.
} 


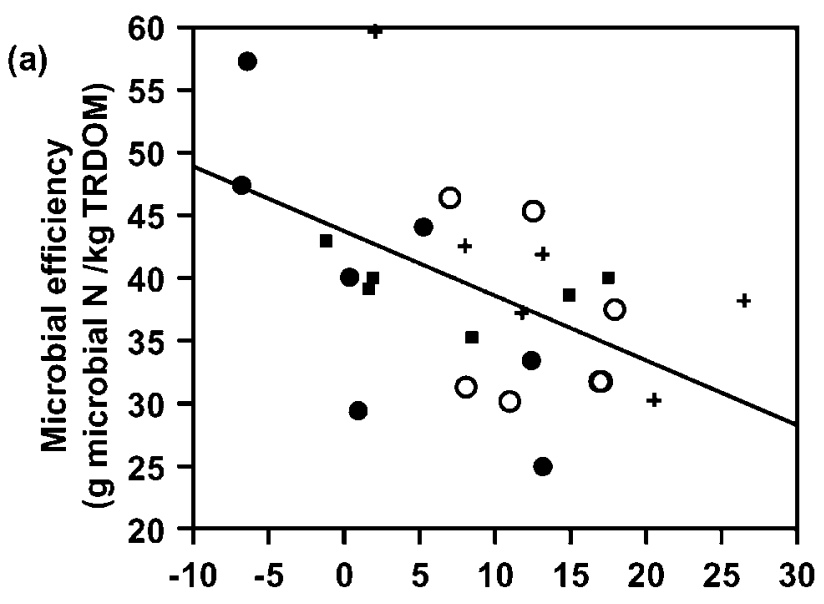

Ruminal starch digestion rate $(\% / h)$

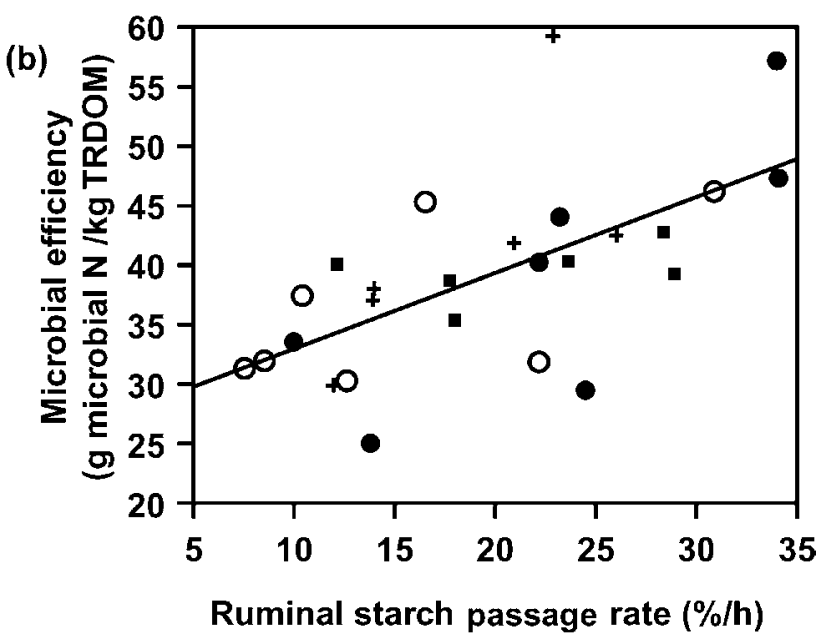

Figure 2. Relationship between microbial $\mathrm{N}$ efficiency (g microbial $\mathrm{N} / \mathrm{kg}$ TRDOM) and (a) ruminal starch digestion rate $(\mathrm{MNE}=43.5-$ $0.5 \times$ starch digestion rate; $\mathrm{R}=-0.52 ; P<0.01$ ); and (b) ruminal starch passage rate $(\mathrm{MNE}=26.5+0.6 \times$ starch passage rate; $\mathrm{R}=$ $0.63 ; P<0.01)$. $\bigcirc$ denotes $0 \%$ beet pulp, + denotes $6 \%$ beet pulp, $\square$ denotes $12 \%$ beet pulp, and - denotes $24 \%$ beet pulp (\% diet DM) substituted for high moisture corn.

tween ruminal starch passage rate and MNE was also demonstrated (Oba and Allen, 2002). The similar responses of MNE in two experiments with very different treatments suggest that, among high-producing cows, the efficiency of microbial protein production is not always affected by ruminal $\mathrm{pH}$ or ammonia concentration, that it is reduced at high rates of starch fermentation, and that it is improved by increased particulate passage rate from the rumen. Although passage rate of particulate digesta affected MNE in this experiment, liquid passage rate was unrelated to MNE (Table 7). Previous experiments have manipulated passage rate in vitro and in vivo for sheep, especially by increasing liquid dilution rate, and have reported responses in microbial protein flow and production, which suggest that increased dilution rate results in greater MNE (Isaacson et al., 1975; Harrison et al., 1976; Kennedy and Milligan, 1978). However, response to liquid passage rate was not separated from the potential concurrent response in particulate passage rate. In addition, the range of dilution rates measured in the present experiment are higher than the ranges of rates reported in previous experiments.

Because liquid passage rate and rumen fluid consistency demonstrated a quadratic relationship, as described earlier, and because fluid consistency was not affected by treatment (Table 4), more than one factor (including consistency) likely affected liquid passage and may have caused particulate and liquid passage to be uncoupled. Wells and Russell (1996) proposed that the rate of microbial turnover $(\% / \mathrm{h})$ decreases geometrically and asymptotically as dilution rate $\left(\mathrm{h}^{-1}\right)$ increases, and that the extent of the effect depends upon microbial lysis rate. The range of individual dilution rates measured in the present experiment (10.6 to $22.9 \% / \mathrm{h}$ ) would fall among and above the top half of dilution rates in the proposed model. Lysis rate was not measured, but assuming that lysis did not occur at the highest rate used in the model $(10 \% / \mathrm{h})$, an increase of $12 \% / \mathrm{h}$ in dilution rate would lead to no more than a $5 \%$ decrease in microbial turnover rate, and, it follows, only a small increase in microbial efficiency. More rapid particle passage rate was therefore much more important than fluid passage rate in improving microbial efficiency. Increasing particulate passage rate removed particle-associated bacteria from the rumen more quickly, which reduced the extent of microbial lysis and increased microbial $\mathrm{N}$ efficiency.

\section{SUMMARY}

Substituting dried, pelleted beet pulp for high-moisture corn from 0 to $24 \%$ of diet DM altered ruminal fermentation but did not affect daily mean or minimum ruminal $\mathrm{pH}$, nor rate of VFA absorption. Among individual observations, ruminal VFA concentration was associated negatively with $\mathrm{pH}$, rate of valerate absorption, and liquid passage rate. Microbial $\mathrm{N}$ efficiency was not affected by replacing high-moisture corn with beet pulp and was not related to ruminal $\mathrm{pH}$, but was increased by greater particulate passage rate.

\section{ACKNOWLEDGMENTS}

The authors thank D. G. Main, R. A. Longuski, Y. Ying, M. Oba, C. S. Mooney, R. A. Kreft, and the staff of the Michigan State University Dairy Cattle Teaching and Research Center for their assistance in this experi- 
ment, and N. K. Ames of the Department of Large Animal Clinical Science in the College of Veterinary Medicine at Michigan State University for performing the cannulation surgeries.

\section{REFERENCES}

Allen, M. S. 1997. Relationship between fermentation acid production in the rumen and the requirement for physically effective fiber. J. Dairy Sci. 80:1447-1462.

Allen, M. S., L. E. Armentano, M. N. Pereira, Y. Ying, and J. Xu. 2000. Method to measure fractional rate of volatile fatty acid absorption from the rumen. Proc. 2000 Rumen Function Conference, Chicago. 25:24.

Anil, M. H., and J. M. Forbes. 1980. Feeding in sheep during intraportal infusions of short-chain fatty acids and the effect of liver denervation. J. Physiol. 298:407-414.

Bach, A., I. K. Yoon, M. D. Stern, H. G. Jung, and H. Chester-Jones. 1999. Effects of type of carbohydrate supplementation to lush pasture on microbial fermentation in continuous culture. J. Dairy Sci. 82:153-160.

Bhatti, S. A., and J. L. Firkins. 1995. Kinetics of hydration and functional specific gravity of fibrous feed by-products. J. Anim. Sci. 73:1449-1458.

Broderick, G. A., and J. H. Kang. 1980. Automated simultaneous determination of ammonia and total amino acids in rumen fluid and in vitro media. J. Dairy Sci. 63:64-75.

Bryant, M. P. 1973. Nutritional requirements of the predominant rumen cellulolytic bacteria. Fed. Proc. 32:1809-1813.

Chester-Jones, H., M. D. Stern, H. M. Metwally, J. G. Linn, and D. M. Ziegler. 1991. Effects of dietary protein-energy interrelationships on holstein steer performance and ruminal bacterial fermentation in continuous culture. J. Anim. Sci. 69:4956-4966.

Clark, J. H., T. H. Klusmeyer, and M. R. Cameron. 1992. Microbial protein synthesis and flows of nitrogen fractions to the duodenum of dairy cows. J. Dairy Sci. 75:2304-2323.

Clark, P. W., and L. E. Armentano. 1997. Influence of particle size on the effectiveness of beet pulp fiber. J. Dairy Sci. 80:898-904.

Crocker, L. M., E. J. DePeters, J. G. Fadel, H. Prez-Monti, S. J. Taylor, J. A. Wyckoff, and R. A. Zinn. 1998. Influence of processed corn grain in diets of dairy cows on digestion of nutrients and milk composition. J. Dairy Sci. 81:2394-2407.

Dado, R. G., and M. S. Allen. 1993. Continuous computer acquisition of feed and water intake, chewing reticular motility, and ruminal $\mathrm{pH}$ of cattle. J. Dairy Sci. 76:1589-1600.

Dijkstra, J., H. Boer, J. Van Bruchem, M. Bruining, and S. Tamminga. 1993. Absorption of volatile fatty acids from the rumen of lactating dairy cows as influenced by volatile fatty acid concentration, $\mathrm{pH}$ and rumen liquid volume. Br. J. Nutr. 69:385-396.

Goering, H. K., and P. J. Van Soest. 1970. Forage Fiber Analysis (Apparatus, Reagents, Procedures, and Some Applications). Agric. Handbook No. 379. ARS-USDA, Washington, DC.

Hach, C. C., B. K. Bowden, A. B. Lopelove, and S. V. Brayton. 1987. More powerful peroxide Kjeldahl digestion method. J. AOAC 70:783-787.

Harrison, D. G., D. E. Beever, D. J. Thomson, and D. F. Osbourn. 1976. Manipulation of fermentation in the rumen. J. Sci. Food Agric. 26:617-620.

Isaacson, H. R., F. C. Hinds, M. P. Bryant, and F. N. Owens. 1975. Efficiency of energy utilization by mixed rumen bacteria in continuous culture. J. Dairy Sci. 58:1645-1659.

Karkalas, J. 1985. An improved enzymatic method for the determination of native and modified starch. J. Sci. Food Agric. 36:10191027.

Kennedy, P. M., and L. P. Milligan. 1978. Effects of cold exposure on digestion, microbial synthesis and nitrogen transformations in sheep. Br. J. Nutr. 39:105-117.

Mansfield, H. R., M. D. Stern, and E. E. Otterby. 1994. Effects of beet pulp and animal by-products on milk yield and in vitro fermentation by rumen microorganisms. J. Dairy Sci. 77:205-216.
Marounek, M., S. Bartos, and P. Brezina. 1985. Factors influencing the production of volatile fatty acids from hemicellulose, pectin and starch by mixed culture of rumen microorganisms. Z. Tierphysiol. Tierernähr. Futtermittelkd. 53:50-58.

O'Mara, F. P., J. J. Murphy, and M. Rath. 1997. The effect of replacing dietary beet pulp with wheat treated with sodium hydroxide, ground wheat, or ground corn in lactating cows. J. Dairy Sci. 80:530-540.

Oba, M., and M. S. Allen. 2000. Effect of brown midrib 3 mutation in corn silage on productivity of dairy cows fed two levels of dietary NDF: 3. Digestibility and microbial efficiency. J. Dairy Sci. 83:1350-1358.

Oba, M., and M. S. Allen. 2003. Effects of diet fermentability on efficiency of microbial nitrogen production in lactating dairy cows. J. Dairy Sci. 86:195-207.

Ørskov, E. R., and C. Fraser. 1975. The effects of processing of barleybased supplements on rumen $\mathrm{pH}$, rate of digestion, and voluntary intake of dried grass in sheep. Br. J. Nutr. 34:493-500.

Overton, T. R., M. R. Cameron, J. P. Elliott, J. H. Clark, and D. R. Nelson. 1995. Ruminal fermentation and passage of nutrients to the duodenum of lactating cows fed mixtures of corn and barley. J. Dairy Sci. 78:1981-1998.

Reynolds, C. K. 1995. Quantitative aspects of liver metabolism in ruminants. Pages 351-372 in Ruminant Physiology: Digestion, Metabolism, Growth and Reproduction, W. v. Englehardt, S. Leonhard-Marek, G. Breves, D. Geisecke, ed. Ferdinand Enke Verlag, Stuttgart, Germany.

Robinson, P. H., C. J. Sniffen, and D. F. Smith. 1985. Development of a one-piece re-entrant cannula for the proximal duodenum of dairy cows. J. Dairy Sci. 68:986-995.

Russell, J. B., C. J. Sniffen, and P. J. Van Soest. 1983. Effect of carbohydrate limitation on degradation and utilization of casein by mixed rumen bacteria. J. Dairy Sci. 66:763-775.

Russell, J. B., and D. B. Wilson. 1996. Why are ruminal celluloytic bacteria unable to digest cellulose at low pH? J. Dairy Sci. 79:1503-1509.

Russell, J. B., W. G. Bottje, and M. A. Cotta. 1981. Degradation of protein by mixed cultures of rumen bacteria: Identification of Streptococcus bovis as an actively proteolytic rumen bacterium. J. Anim. Sci. 53:242-252.

Satter, L. D., and L. L. Slyter. 1974. Effect of ammonia concentration on rumen microbial protein production in vitro. Br. J. Nutr. 32:199-208.

Strobel, H. J., and J. B. Russell. 1986. Effect of pH and energy spilling on bacterial protein synthesis by carbohydrate-limited cultures of mixed rumen bacteria. J. Dairy Sci. 69:2941-2947.

Van Kessel, J. S., and J. B. Russell. 1996. The effect of amino nitrogen on the energetics of ruminal bacteria and its impact on energy spilling. J. Dairy Sci. 79:1237-1243.

Van Soest, P. J., J. B. Robertson, and B. A. Lewis. 1991. Methods for dietary fiber, neutral detergent fiber and nonstarch polysaccharides in relation to animal nutrition. J. Dairy Sci. 74:35833597.

Voelker, J. A., and M. S. Allen. 2003a. Pelleted beet pulp substituted for high-moisture corn: 1 . Effects on feed intake, chewing behavior, and milk production in lactating dairy cows. J. Dairy Sci. 86:3542-3552.

Voelker, J. A., and M. S. Allen. 2003b. Pelleted beet pulp substituted for high-moisture corn: 2. Effects on digestion and rumen digestion kinetics in lactating dairy cows. J. Dairy Sci. 86:3553-3561.

Wallace, R. J., and C. A. McPherson. 1987. Factors affecting the rate of breakdown of bacterial protein in rumen fluid. Br. J. Nutr. 58:313-323.

Wells, J. E., and J. B. Russell. 1996. Why do so many ruminal bacteria die and lyse so quickly? J. Dairy Sci. 79:1487-1495.

Williams, C. H., D. J. David, and O. Iismaa. 1962. The determination of chromic oxide in feces samples by atomic absorption spectrophotometry. J. Agric. Sci. 59:381-385.

Zinn, R. A. and F. N. Owens. 1986. A rapid procedure for purine measurement and its use for estimating net ruminal protein synthesis. Can. J. Anim. Sci. 66:157-166. 